\title{
INTERNET MARKETING I MEDIJSKA PROMOCIJA OBRAZOVNIH USTANOVA
}

\author{
Slobodan Vuletić ${ }^{1}$, Vojislav Todorović \\ ${ }^{1} O S ̌$ "Kosta Trifković" Novi Sad \\ 2OŠ "Dušan Dugalić" Beograd
}

\begin{abstract}
:
U radu se ispituju i kritički analiziraju mogućnosti obrazovnih ustanova da se u savremenom poslovnom okruženju promovišu putem Interneta. Ugled i reputacija javnih institucija moraju se održavati primenom savremenih komunikacionih i marketinških strategija, medijskom promocijom i održavanjem dobrih odnosa s javnošću. Ka tom cilju trebalo bi krenuti naučnim putem primenom savremenih komunikoloških znanja i interdisciplinarnih dostignuća iz oblasti informatike, ekonomije, marketinga, menadžmenta i psihologije. Informatizacija društva zahteva nove pristupe društvenom komuniciranju, pa tako unapređivanje komunikacione prakse postaje imperativ. Taj imperativ se postavlja i pred obrazovne ustanove koje bi trebalo da vrše organizaciono usklađivanje prema zahtevima savremenog društva i da razvijaju i primenjuju komunikacione i marketinške strategije u planiranju i organizovanju svakodnevnih aktivnosti. Savremene marketinške strategije podrazumevaju primenu Interneta u kontekstu i perspektivi. Marketinške strategije pomažu radnim organizacijama da se pozicioniraju i promovišu u svom okruženju i time unaprede svoje poslovanje.

Obrazovne institucije, kao važni društveni subjekti, zajedno sa ostalim organizacijama ulaze u tržišni odnos i započinju "tržišnu utakmicu" sa drugim organizacijama. Da bi se u toj tržišnoj utakmici opstalo, u organizacionom i logističkom smislu, neophodno je kontinuirano razvijati ekonomske, marketinške i komunikacione strategije na globalnom i lokalnom nivou, uključujući Internet kao moćan elektronski medij koji se učestalo koristi u svrhu medijske promocije.
\end{abstract}

\section{Key words:}

Internet,

marketing,

obrazovne ustanove,

mediji,

promocija.

\section{UVOD}

Internet predstavlja novu okosnicu tehnološkog razvoja i primene inovativnog znanja. Ustanove koje ostvaruju profit svojim poslovanjem, svakodnevno dokazuju moć novih medija kao što je Internet, jer je to moćan kanal putem kog se lako i brzo dolazi do kupaca, klijenata i uopšte do tržišta. Sve češće, kupci sami putem pretrage ili oglasa dolaze do proizvoda i to se čini kao poseban deo marketinške strategije privlačenja.

Gde se na toj relaciji nalaze obrazovne ustanove i da li se može podvući paralela sa ostalim organizacijama imajući u vidu određene specifičnosti? Promene koje se dešavaju u oblasti obrazovanja mogu se objektivno opisati interdisciplinarnim pristupom analiziranjem položaja ustanova sa pravnog, sociološkog, ekonomskog, politič- kog, pedagoškog i komunikološkog aspekta, što se čini kao krajnje složen zadatak. Promene koje se trenutno događaju u školama u Srbiji, kreću se u smeru liberalizacije i one iz više razloga postepeno prerastaju u samostalne organizacije, koje država kao osnivač finansira sa zakašnjenjem, i ujedno ih primorava da se okreću sponzorstvu i samostalnom pribavljanju materijalnih sredstava za rad. U skladu sa tim promenama obrazovanje postaje brend, a obrazovne ustanove čine se kao radne jedinice koje osim što vrše pedagošku funkciju u društvu, doprinose tehničkom, kulturnom i ekonomskom razvoju zajednice sa dugoročnim efektima. Medijska promocija i dobri odnosi s javnošću osnovnih škola čine se kao pravi korak na putu privlačenja većeg broja učenika, roditelja, sponzora, odgovornih ljudi iz lokalne zajednice ali i kvalitetnih nastavnika koji čine važan segment ciljne javnosti. 
Obrazovnim ustanovama je zato potrebno određeno organizaciono usklađivanje, prema posebnim potrebama koje zavise od primene komunikacionih i marketinških strategija radi medijske promocije. Kao odličan kanal nameće se Internet. Primena informaciono-komunikacionih tehnologija u svakodnevnom životu građana doprinosi kvalitetnijem i modernijem načinu života i povećava uključenost u "javnu sferu" a ne zahteva mnogo novih ulaganja u opremu. Radne organizacije bi trebalo da putem Interneta vrše medijsku promociju i da se oglašavaju, reklamiraju i prezentuju.

\section{UPOTREBA INTERNETA U SRBIJI}

Pojava Interneta se naziva još i "drugo medijsko doba". To znači da se nakon pojave i primene Interneta, komunikacija promenila u pravcu primene novih tehnologija u svakodnevnom životu. Internet se definiše kao "opšteprihvaćen naziv za globalni sistem kompjuterskih mreža. Čini ga neograničen i stalno rastući broj pojedinačnih kompjutera, lokalnih i globalnih mreža na Zemlji" (Miletić, 2012:78). Kao globalni sistem, nudi mogućnosti brzog i lakog prenosa informacija.

U savremenom poslovanju upotreba Interneta je nezaobilazna stavka. Upotreba računara i Interneta u Srbiji povećana je tokom 2013. godine, što dokazuju rezultati istraživanja Republičkog zavoda za statistiku o upotrebi informaciono-komunikacionih tehnologija. Prema rezultatima istraživanja ove relevantne ustanove, u Srbiji 58,9\% domaćinstava poseduje računar, što predstavlja povećanje od $4,7 \%$ u odnosu na 2012. godinu. 55,8\% domaćinstava poseduje Internet priključak, što je $8,3 \%$ više u odnosu na 2012. godinu, a čak 14,6\% više u odnosu na 2011. godinu. Računare u Srbiji svakodnevno koristi preko 2,600.000 lica, što znači da se broj lica koji svakodnevno koristi računar u 2013. godini povećao za 100.000 u odnosu na 2012. godinu.

$\mathrm{Na}$ osnovu ovih podataka, može se zaključiti da se Internet u Srbiji razvija i da građani koriste njegove mogućnosti. To je značajan podatak koji otvara nove mogućnosti promovisanja i razvoja marketinga putem Interneta. Posebno je značajan podatak da nalog na društenim mrežama Fejsbuk i Tviter ima 93,4\% Internet populacije od 16 do 24 godine. Uočljiv je i trend porasta broja domaćinstava koja pristupaju Internetu putem mobilnog telefona. Čak - 46,1\% domaćinstava koristilo je mobilni telefon za pristup Internetu, što u odnosu na rezultate iz 2012. godine predstavlja povećanje od $8,9 \%$. Dakle, društvene mreže imaju posebno učešće u životu korisnika Interneta, te je to važan podatak za razvoj marketing strategija i oglašavanje. Kada je reč o preduzećima u Srbiji, 100\% preduzeća sa više od 10 zaposlenih koristi računar u svom poslovanju, što predstavlja povećanje za 1,3\% u odnosu na 2012. godinu. $73,8 \%$ preduzeća koja imaju Internet priključak poseduje svoju web prezentaciju, s tim što $11,1 \%$ web prezentacija preduzeća u Srbiji omogućava on-line plaćanje dok 24,7\% omogućava on-line naručivanje ili rezervisanje proizvoda i/ili usluga.

Sprovedeno istraživanje ove ustanove pokazuje da $26,1 \%$ Internet populacije koristi Internet usluge, ume- sto da ostvaruje lične kontakte ili da posećuje javne ustanove ili organe administracije. Dakle, škole bi kao javne ustanove trebalo da imaju kvalitetno urađen web sajt kao komunikacioni kanal putem kojeg bi ne samo održavale odnose s javnošću, nego informisale i privlačila građane, promovisale samu instituciju, nastavnike i (postojeće i buduće) učenike.

\section{INTERNET MARKETING}

Ako se o Internetu govori u okviru medijskog diskursa, za razliku od prethodnih medija putem kojih se vršio marketing, kao što su štampa, televizija ili radio, Internet omogućava brzu i dvosmernu komunikaciju. U tom kontekstu "Internet je prvi globalni dijaloški medij" (Duronjić, 2011:188). Internet u tom smislu postaje komunikacijski centar za razmenu mišljenja ili za prenos poruka različitog značenja za primaoce. U komunikološkom smislu, informacije koje se pohranjuju na Internetu su uvek dostupne i stalno se ažuriraju i dopunjuju. To nudi mogućnost vraćanja na informacije, dopunjavanja i stvaranja novih značenja. To se shvata kao medijska konvergencija, jer se u Internet "slivaju" svi prethodni mediji i mogućnosti se proširuju velikom brzinom. Hipertekstualnost, multimedijalni sadržaji i interaktivnost neke su od karakteristika komunikacije putem Interneta.

Internet marketing predstavlja vrlo praktičnu formu marketinga koja podrazumeva korišcenje pretraživanja i prezentovanja na Internetu u cilju sticanja pre svega profita ali i promocije. Dakle, korisnici nekog proizvoda ili potrošači, putem Interneta mogu brzo i lako da stupe u kontakt sa željenom kompanijom ili preduzećem koje se promoviše ili promoviše neki proizvod ili uslugu. Marketing se shvata kao "praksa funkcionisanja privrednih organizacija zasnovana na tržišnim principima ili kao skup promotivnih aktivnosti određene društvene organizacije" (Miletić, 2012:167). Svaka savremena organizacija može uspešno poslovati samo ako postoji usaglašenost između ponude i potražnje određenih usluga ili proizvoda. Savremeni marketing se ostvaruje putem marketinškog miksa izrađenog u formuli 4P: Product (proizvod), Price (cena), Placement (plasman), Promotion (promocija). Dve marketinške strategije pull (vučenje ili privlačenje) ili push (guranje) se primenjuju u zavisnosti od ponude i potražnje na određenom tržištu. "Strategija privlačenja se često koristi kada je potražnja veća od ponude" i to putem određene promocije (Miletić, 2012:168).

Sa druge strane, strategija guranja naglašava promociju koja razvija potrebe potrošača do određene mere, čime se potrošači prvenstveno podstiču da kupuju određene proizvode ili da koriste određene usluge nezavisno od zadovoljavanja njihovih realnih potreba. Dakle akcenat je u prvom slučaju na promociji robe ili usluga. Ovakav novi vid marketinga često se nalazi pod sličnim nazivima "on-line marketing", "virtuelni marketing", "Internet marketing" ili marketing na Internetu i najcešće se shvata kao zadovoljenje potreba i zahteva svih potrošača pre svega za informacijama. Internet marketing nudi dvosmernu komunikaciju sa ciljnim grupama kao korisnicima, putem Interneta kao kanala komuniciranja. U većini slučajeva aktivnosti na 
polju odnosa s javnošću ili PR-a "mogu da obezbede bolji povraćaj investicije nego marketinške komunikacije kao što su oglašavanje, direktan marketing i promocija prodaje" (Davis, 2005:324).

Internet je savremeni medij marketinga koji funkcioniše uz najveće iskorišcenje troškova. U skladu sa tim su i novija istraživanja relevantnih republičkih ustanova čije podatke smo naveli. Zato pod pojmom Internet marketinga podrazumevamo savremeni on-line marketing koji se odnosi na sprovođenje marketing ideje korišćenjem javne i međunarodne kompjuterske Internet mreže. $U$ interaktivnoj komunikaciji dopušta se obavljanje različitih aktivnosti kao sto su dijalog, prikupljanje informacija, širenje obaveštenja o proizvodima i uslugama, rešavanje odredjenih tržišnih problema i prikupljanje adresa kupaca, korisnika usluga ili drugih partnera kao što su nevladine organizacije. Za ovakvu interaktivnu komunikaciju, neophodno je vršiti dobru Internet promociju. Postoje više vidova Internet promocije ali najčešći načini su putem web prezentacije ili putem e-mail marketinga. $U$ ostvarenju Internet marketing važno je posedovanje prezentacije.

Web prezentacija (website) je predstavljanje firme na Internetu, putem stranica koje sadrže ključne informacije o datoj organizaciji. Reklama na bilo kom segmentu Interneta treba da vodi datog korisnika do prezentacije na kojoj će potencijalni kupac ili korisnik usluga moći detaljnije da sazna sve aktuelne informacije o organizaciji i ako je zainteresovan, da komunicira sa dotičnom organizacijom prvenstveno preko e-mail servisa koji je vidljiv na Internet stranici (website).

E-mail marketing kao drugi korak predstavlja direktnu komunikaciju sa korisnikom. Važne su tehničke, grafičke i multimedijalne karakteristike sajta koje bi trebalo da su primamljive svakom ko poseti stranicu. Moguće je i pružanje vesti o novim proizvodima i uslugama koje imaju afirmativno delovanje. Kultura komunikacije na Internetu za sve navedene aktivnosti podrazumeva da se ona može sprovoditi samo u slučaju kada korisnik sam želi informacije i to kada se prijavi na e-mail listu. Ovo se postiže time sto se na prezentaciji nalazi formular putem kog korisnik prijavljuje svoju e-mail adresu na koju će posle dobijati cilkularnu poštu (newsletter) ili promotivne brošure. To znači da će se pod kvalitetnom poslovnom komunikacijom putem e-mail servisa podrazumevati dvosmerna komunikacija uz prethodno dobijenu dozvolu od strane korisnika. Naime, korisnik daje dozvolu da na njegovu e-mail adresu stižu poruke i korisnik se dobrovoljno prijavljuje da prima odredene sadržaje. U cirkularne mailing liste spadaju promotivne liste koje su komercijalne, informacione liste koje mogu biti komercijalne ili nekomercijalne, kao i diskusione liste koje takođe mogu biti komercijalne ili nekomercijalne. Direktan marketing predstavljaju promotivne aktivnosti firme, koje imaju za zadatak direktan ulazak u stan kroz letak, pismo, brošuru, lično prisustvo, telefon, fax.

Ovakav direktan marketing ima za cilj povećanje prodaje proizvoda ili usluge.
U slucaju Interneta, direktan marketing predstavlja komunikacija organizacije ili (pojedinca) sa potencijalnim klijentom preko e-maila.

Upotreba bloga se takođe može smatrati korisnom u Internet marketignu jer se korisnici bloga osim informisanja, mogu bolje upoznati sa određenim proizvodom ili uslugom i to zahvaljujući dvosmernoj komunikaciji sa licima koja vode blog ili koja su na njemu aktivna.

Bilteni i druge knjige u elektronskoj formi mogu da se šalju putem e-maila i da na taj način promovišu rad jedne organizacije. Baneri drugi oblici plaćenog oglašavanja su vrlo korisni u Internet marketingu jer se mogu pronaći na Internet stranicama na kojima je velika frekvencija korisnika Interneta. To se najčešće može ostvariti na posebnim stranicama ili u okviru već postojećih sajtova koje u okviru svog prostora nude prostor za oglašavanje.

$\mathrm{Na}$ osnovu navedenih aktivnosti koje se vrše u svrhu marketinga, treba istaći da su veoma korisne integrisane marketinške komunikacije (IMC). One podrazumevaju integraciju različitih instrumenata komunikacije koji se koriste za promociju kao deo marketinga, jer zahvaljujući tom principu "postoji integracija svih aktivnosti horizontalno po svim elementima marketing miksa i po svim sektorima i službama u organizaciji" (Davis 2005:139).

\section{ISTRAŽIVANJE}

\section{Analiza Internet prezentacija osnovnih škola}

Ovo istraživanje je obavljeno u dva koraka. U prvom delu istraživanja metodom analize sadržaja materijala dostupnog na Internet prezentaciji, analizirano je osam sajtova škola. Cilj prvog dela istraživanja bio je da se utvrdi da li škole putem svojih sajtova vrše marketinšku funkciju. Analizirano je osam školskih sajtova. Država je osnivač za sedam škola dok je analiziran i sajt jedne privatne osnovne škole. Sve škole se nalaze na teritoriji opštine Novi Sad.

Problem koji smo istražili jeste pitanje da li su Internet prezentacije osnovnih škola na teritoriji opštine Novi Sad $\mathrm{u}$ funkciji Internet marketinga i da li one vrše ulogu medijske promocije škole.

Uvidom u sadržaje Internet prezentacije navedenih škola, može se primetiti da su pojedini sajtovi škola dvojezični, na mađarskom i na srpskom jeziku. Sajtovi u načelu

Tabela 1. Analiza sajtova osnovnih škola

\begin{tabular}{|c|c|}
\hline \multicolumn{2}{|l|}{ Osnovne škole iz Novog Sada } \\
\hline Naziv škole & Internet adresa \\
\hline $\begin{array}{l}\text { 1. OŠ "Nikola Tesla" } \\
\text { 2. OŠ "Dositej Obradović" } \\
\text { 3. OŠ "Žarko Zrenjanin" } \\
\text { 4. OŠ "Jovan Popović" } \\
\text { 5. OŠ "Jožef Atila" } \\
\text { 6. OŠ "Dušan Radović" } \\
\text { 7. OŠ "'Svetozar Marković Toza" } \\
\text { 8. OŠ "Miroslav Mika Antić" }\end{array}$ & $\begin{array}{l}\text { http://www.osnikolateslans.edu.rs/ } \\
\text { http://www.dositejns.edu.rs/ } \\
\text { http://zarkons.edu.rs/ } \\
\text { http://www.jovanpopovic.edu.rs/ } \\
\text { http://www.jatila.edu.rs/kontakt.html } \\
\text { http://dusan-radovic.znanje.info/ } \\
\text { http://www.toza.edu.rs/ } \\
\text { http://www.skolamikaantic.edu.rs/ }\end{array}$ \\
\hline
\end{tabular}


ispunjavaju svrhu Internet prezentacije ali ne koriste sve škole mogućnosti Internet marketinga i promocije putem istog u dovoljnoj meri.

Jedna od bitnih osobina sajta OŠ "Nikola Tesla" je deo koji prikazuje koliko se škola prikazuje u medijima taksativno po datumima i u kojim medijima je škola bila. To dokazuje da rukovodstvo škole vodi računa o marketingu $\mathrm{i}$ ističe ga putem Internet prezentacije. Takođe navedena škola ima stranicu na sajtu Facebook, a osim nje, od analiziranih sajtova OŠ "Žarko Zrenjanin", OŠ "Jožef Atila" i privatna OŠ "Mika Antić". Dakle, 4 škole od 8 imaju zvanične stranice na društvenoj mreži Facebook. Blogovi se nalaze na sajtovima pojedinih škola dok se i prikazuju aktivnu saradnju same škole sa poslovnim partnerima. $\mathrm{Na}$ sajtu OŠ "Žarko Zrenjanin"postoji deo koji se bavi medijima nazvan PRESS, gde se nalaze podaci o prisutnosti škole u medijima. Ovaj deo je ažuriran i sa novim je podacima o prisustvu škole na radiju u štampi i na televiziji. Škola svoje poslove u okviru javnih nabavki prikazala je i na samom sajtu čime ističe transparentnost u radu što se može protumačiti i kao dobar marketinški potez. Ako govorimo o evropskim standardima kvaliteta prezentacije, škola na teritoriji grada Novog Sada, onda je prezentacija OŠ "Svetozar Marković Toza" jedna od najkvalitetnijih. Sajt ima formu na dvanaest jezika i prevodi se preko Google translate. Svakako to zbog višenacionalnosti u Vojvodini i samog pristupa Srbije Evropskoj uniji, pruža posetiocima različitih nacionalnih manjina $\mathrm{u}$ Vojvodini ili gostima iz EU mogućnost da se lagodno osećaju kad posećuju sajt škole koja neguje multikulturalnost.

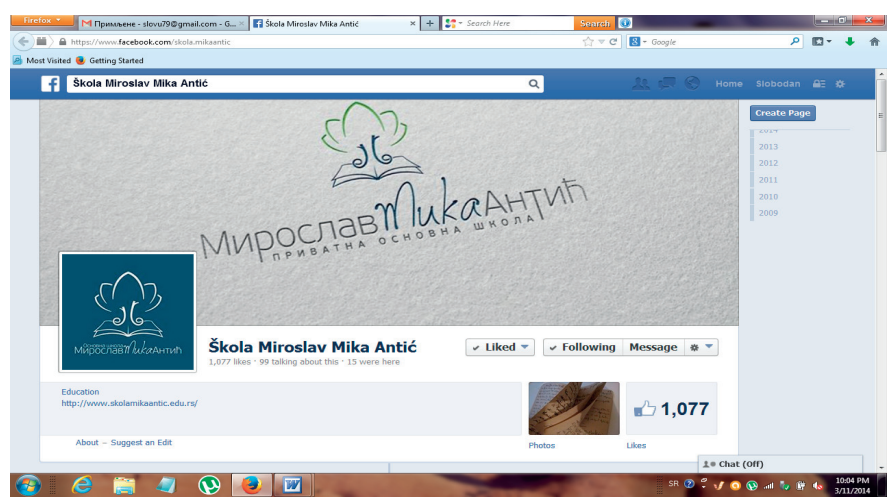

Sl.1. Izgled sponzorisane stranice OŠ "Miroslav Mika Antić" na društvenoj mreži Facebook

Sajt privatne Osnovne škole "Miroslav Mika Antić", je vrlo moderan i roditelji imaju pristup na sajtu škole elektronskom dnevniku. Potrebno je da imaju svoje korisničko ime i lozinku. Novosti škole prikazane su na sajtu sa veoma ažuriranim podacima.

Za razliku od ostalih škola u gradu Novom Sadu privatna OŠ "Miroslav Mika Antić" na svom sajtu ima kutak za roditelje. Škola se sponzoriše na sajtu Facebook i na taj način svakodnevno okuplja nove korisnike Interneta. $\mathrm{Na}$ zvaničnoj stranici se lako nalaze link do sajta škole. $\mathrm{Na}$ Facebook stranici postoje i galerije fotografija i video snimci čime se vrši marketinška funkcija putem Interneta. Stranica je bogata sadržajima o savremenim metodama učenja, podaci se redovno ažuriraju i predstavljaju rezultate učenika škole i njihovih nastavnika u zajedničkom radu. Stranica ove škole je u potpunosti u funkciji Internet marketinga.

Zaključak koji se može izvesti na osnovu komparacije sadržaja sajtova osnovnih škola, je da pojedine škole uviđaju značaj novih medija i delimično se promovišu putem Interneta, čime delimično vrše marketinšku funkciju. Uvidom u sajtove stiče se zaključak da je potreban dodatni rad kako bi rukovodstvo škola učinilo Internet prezentaciju otvorenijom za pripadnike ciljne javnosti i omogućilo dvosmernu komunikaciju.

\section{Analiza stavova nastavnika o Internet marketingu}

U drugom delu istraživanja učestvovalo je 36 nastavnika i učitelja OŠ "Kosta Trifković" iz Novog Sada. Što se tiče polne strukture ispitanika, najveći procenat $69,4 \%$ je ženskog pola, dok je 30,6\% ispitanika muškog pola. Svi ispitanici imaju radno iskustvo u prosveti a najviše ispitanika $44 \%$ radi više od 10 godina na radnom mestu nastavnika. Tehnikom anketiranja utvrđeni su stavovi i mišljenja nastavnika o Internet marketingu obrazovnih ustanova. Upitnik je činilo 9 pitanja zatvorenog tipa, dok je deseto pitanje bilo otvorenog tipa i ispitanici su imali prilike da iznesu svoj predlog unapređivanja promocije škole putem Interneta.

\section{Tabela 2. Upotreba interneta}

\begin{tabular}{|l|c|c|}
\hline \multicolumn{2}{|l|}{ Koliko često koristite Internet? } \\
\hline & $\mathrm{N}$ & $\%$ \\
\hline Svakodnevno & 35 & 97.2 \\
\hline Povremeno & 1 & 2.8 \\
\hline Total & 36 & 100.0 \\
\hline
\end{tabular}

Svi ispitanici koriste Internet svakodnevno, što je visok procenat. Od svih ispitanika $80,6 \%$ koristi društvene mreže a najčešće se posećuje društvena mreža Facebook. Najveći broj ispitanika ili 94,4\% nema svoj blog, dok 5,6\% ima svoj blog.

Sledećim pitanjem smo želeli utvrditi da li ispitanici prate rad blogova i učestvuju li u radu nekog bloga pojedinca, grupe ili institucije.

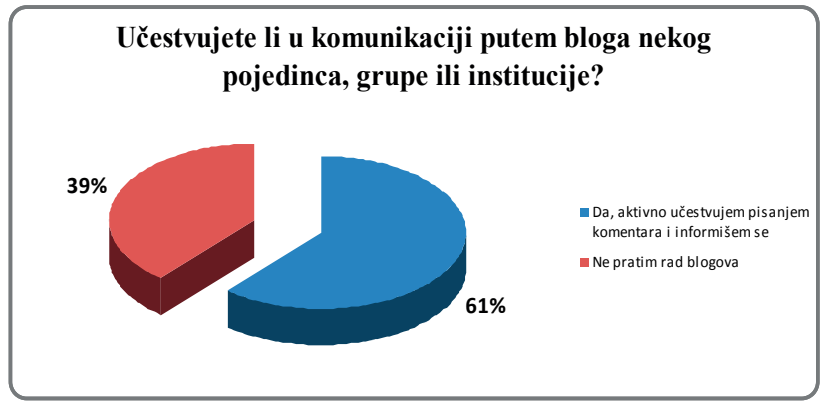

S1. 2. Učestvovanje ispitanika u radu nekog bloga

Većina ispitanika ili 61\% aktivno prati rad nekog bloga, piše komentare i informiše se o stručnim temama, dok 39\% ispitanika tvrdi da ne prati rad nekog bloga. To pokazuje da nastavnici upotrebljavaju svoj ili tuđi blog 
kao vid komunikacije i taj podatak je vrlo značajan jer se blogovima može vršiti dobar Internet marketing obrazovnih ustanova, a nastavnici kao predstavnici ciljne javnosti mogu da budu promoteri, diseminacijom informacija $u$ stručnim krugovima.

Nastavnici uviđaju značaj postojanja organizacijskog bloga i njegov uticaj na unapređenje komunikacije. Taj podatak može biti vrlo interesantan prosvetnim vlastima koje bi trebalo da osavremene sajtove i da uvedu i ovakav oblik komunikacije medju zaposlene radnike. Na pitanje o učestalosti posete sajta škole ukojoj su zaposleni približno $90 \%$ ispitanika ima naviku da posećuje sajt svoje škole kako bio se informisao o aktuelnostima. Na osnovu ovog podatka može se zaključiti da se nastavnici zaposleni u školi na neki način interesuju za aktivnosti u školi. To je važan podatak jer pokazuje da nastavnici imaju informatička znanja i navike kao i potrebu da posećuju sajt škole u kojoj su zaposleni, kako bi se informisali o pojedinostima. Informisanost nastavnika, učenika i roditelja smatra se vrlo važnim faktorom zainteresovanosti za praćenje rada jedne ustanove.

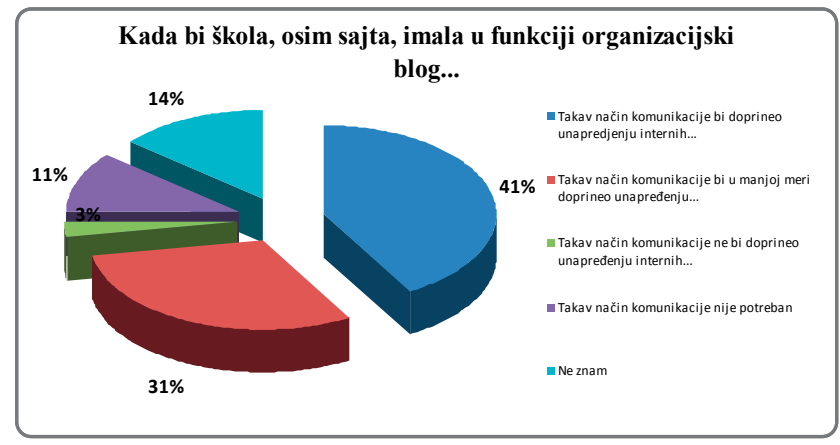

Sl. 3. Mišljenja ispitanika o mogućnosti funkcionisanja organizacijskog bloga u okviru sajta škole i njegovog uticaja na komunikaciju

Većina ispitanika smatra da je školama potrebna dodatna medijska promocija kao vid marketinških aktivnosti. Ovakvi stavovi su u skladu sa prethodnim stavovima kojima se pokazuju navike i mišljenja ispitanika.

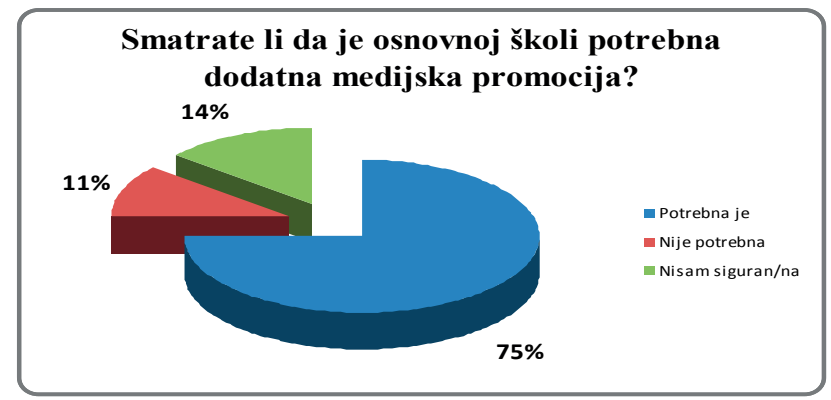

Sl. 4. Odgovor ispitanika na pitanje o dodatnoj promociji škole u medijima

Ispitani nastavnici pokazuju da poseduju svest o značaju promocije obrazovne ustanove u novom medijskom okruženju. Ispitanici se slažu sa činjenicom da je školama potreban moderan sajt i da bi trebalo da bude primamljiv ciljnim grupama kao što su: roditelji, učenici, nastavnici, predstavnici medija i predstavnici lokalnih vlasti.

Dodatna promocija škole i školskih aktivnosti je potrebna i iz razloga što u poslednje vreme mediji senza- cionalistički izveštavaju o incidentima maloletnika izvan škole. To se često pogrešno interpretira i dovode u vezu sa nastavnicima, čime se stvaraju negativni stavovi i mišljenja o tome da se u školama ne radi kvalitetno ili da se "ne radi dovoljno".

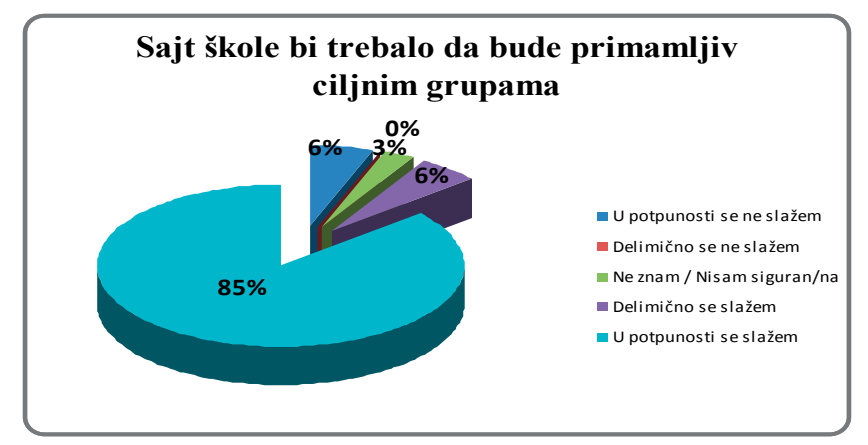

Sl. 5. Mišljenja ispitanika o funkciji sajta u svrshu privlačenja ciljnih grupa

Dakle, nastavnici uočavaju potrebu da školski sajt izgleda "primamljivo" i to je u skladu sa marketinškom strategijom privlačenja ciljnih grupa. Čak 91\% ispitanika smatra da bi sajt škole trebalo da bude lako dostupan preko pretraživača, čime bi se olakšalo predstavnicima ciljnih grupa da dođu do njega. U te svrhe se koriste različite optimizacije i prosvetne vlasti bi trebalo da imaju u vidu i takve mogućnosti Interneta.

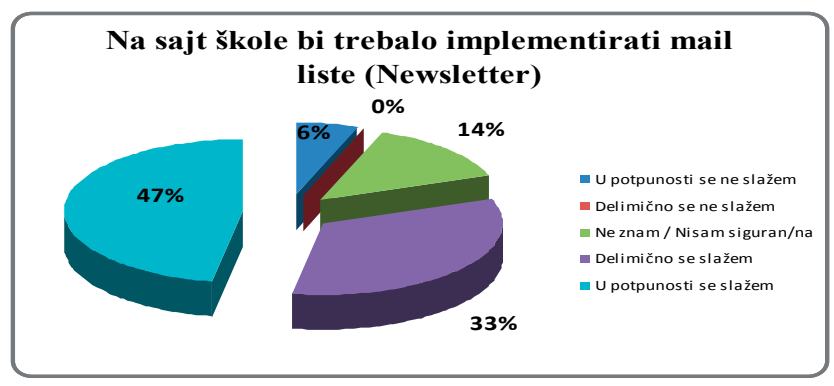

Sl. 6. Implementacija mailing liste u školski sajt

Visok procenat ispitanika ili $80 \%$ uočava značaj mailing lista na sajtovima. To znači da 4 od 5 spitanika smatra da bi mailing liste doprinele promociji škole. Na taj način bi ciljne grupe primale nove informacije (Newsletter), brošure i biltene koje škola inače izrađuje i postavlja u nekom delu sajta. Na taj način bi se doprinelo boljoj informisanosti pripadnika ciljne javnosti o aktivnosti škola i ostvarenim rezultatima kao i razvoju Internet marketinga obrazovnih ustanova.

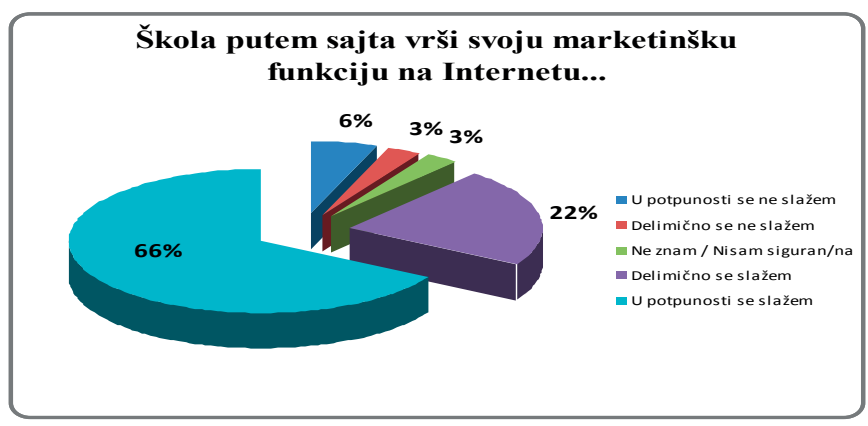

Sl. 7 Odgovori ispitanika na pitanje da li je prezentacija osnovne škole u funkciji Internet marketinga. 
$\mathrm{Na}$ osnovu odgovora ispitanika na ovo pitanje zaključuje se da čak $88 \%$ nastavnika smatra da školski sajt vrši svoju marketinšku funkciju na Internetu.

Ovakav stav je u skladu sa prethodnim stavovima i mišljenjem ispitanika jer su na osnovu ovih pitanja pokazali da uočavaju značaj promocije škole savremenim metodama kao i da su informatički "pismeni". Nastavnici jasno uočavaju potrebu da se škole promovišu putem Interneta i da na taj način vrše marketinšku funkciju u skladu sa savremenim medijskim okruženjem.

Profesori su dali i neke od predloga unapređenja sajta a navode se neki od njih: da škole ažuriraju podatke na sajtu, da se beleže i prikazuju snimci sa sajta Youtube sa školskih takmičenja, da škola ima stranicu na sajtu Facebook, da profesori izlože svoje radove i nagrade, kao i to da se na sajtu poseduje karton zaposlenog radnika sa odgovarajućim podacima.

\section{ZAKLJUČAK}

$\mathrm{Na}$ osnovu analize sajtova i tumačenja rezultata ankete, stiče se utisak da je Internet marketing u školama kao obrazovnim ustanovama u "početnoj fazi". Na osnovu analize prisustva škola na društvenim mrežama, čini se da su se privatne obrazovne ustanove brže uključile u tržišnu utakmicu jer su im sajtovi kvalitetniji i privlačniji. Promocija i izgled web sajta imaju veliku ulogu u funkcionisanju rada škola jer nude velike mogućnosti direktnog dolaska do klijenata ili korisnika usluga obrazovanja.

Strategijom privlačenja škole bi trebalo da se ugledaju na privatne obrazovne ustanove i da okupljaju na društvenim mrežama nove pripadnike ciljne javnosti i da se adekvatnije promovišu putem Interneta. Kao jedno od objašnjena za to je verovatno način finansiranja, odnosno pitanje da li je osnivač država ili privatno lice.

Školama čiji je osnivač država, nedostatak učenika za sada ne predstavlja egzistencijalni problem, ali se on povećava iz godine u godinu. Škole koje se bolje promovišu putem medija, imaju veću šansu da svojim kadrovima obezbede egzistenciju u narednim godinama a samim tim i obavezu da se školovanje učenika odvija po najvišim obrazovnim standardima.

Kako su škole neprofitne ustanove, pogodan je i poželjan "socijalni marketing" koji može da neguje ili da menja društvena ponašanja. Besplatno oglašavanje je vrlo korisno u onim segmentima koji to dozvoljavaju kao što su besplatne stranice sa oglasima itd. Kao nove mogućnosti besplatnog oglašavanja ili oglašavanja koje može biti vrlo jeftino u odnosu na televizijske ili radio emisije, pronalaze se društvene mreže Facebook ili Twitter koje okupljaju milionski broj korisnika Interneta.

Sve veći broj mladih korisnika na Internetu i društvenim mrežama čini da se one smatraju vrlo pogodnim kanalom putem kojeg se može ostvariti Internet marketing obrazovnih ustanova.
Pošto u obrazovnim institucijama nije dovoljno razvijena služba PR-a, smatramo da bi jedno od rešenja pitanja promocije obrazovnih ustanova bile upravo integrisane marketinške komunikacije, putem kojih bi se u integrisanim horizontalnim i vertikalnim aktivnostima vršila promocija ustanove sa elementima marketinga.

Kao drugo rešenje problema, smatra se pogodnim razvoj marketinških odnosa s javnošću, jer uključuju PR aktivnosti sa elementima marketing miksa $(4 \mathrm{P})$ i povezuju ljude (nastavnike kao kadrove) i druge fizičke dokaze kao što je korporativni identitet u svrhu promocije. U tom slučaju marketing bi se vršio kao deo PR-a putem Internet prezentacije.

U pripremanju ovog rada primećeno je da su potrebna obimnija istraživanja problematike Internet marketinga u obrazovnim ustanovama i da bi ova istraživanja trebalo proširiti i na roditelje kao pripadnike ciljne javnosti.

Kako su ispitanici potvrdili da sajt škole jeste u funkciji Internet marketinga, trebalo bi da nadležno Ministarstvo prosvete ima bolju komunikaciju unutar same institucije i da razvija interne i eksterne odnose s javnosću, te da uvažava predloge profesora koji poznaju problematiku i osećaju se direktno involvirani jer se kreativno postavljaju u rešavanju svakodnevnih zadataka u promovisanju škole.

Posebno bi trebalo razvijati i optimalizovati sajtove škola kao i pojačati finansiranje i ulaganje u promociju i marketing obrazovnih ustanova.

\section{LITERATURA}

[1] A. Davis, "Public relations", "Sve što treba da znate o odnosima s javnošću, Graph Style, Novi Sad 2005.

[2] J. Habermas, "Javno mnenje, Istraživanje u oblasti jedne kategorije građanskog društva", Kultura, Beograd 1969.

[3] T. T. Đuronjić, "Komuniciranje u medijasferi", Bard fin d.o.o., Beograd 2011.

[4] Sajt Republičkog zavoda za statistku, posećen 7.03.2014. http://webrzs.stat.gov.rs/WebSite/Public/PageView. aspx?pKey=205

[5] Sajt sa informacijama o blogovima posećen 8.03.2014. http://sbinformation.about.com/cs/ecommerce/a/bblogs. htm

[6] D. S. Subotić, "Javno upravljanje i modernizacija javnog sektora Srbije, "Politička revija, vol. 9, br. 2,2010. str. 65-102

[7] D. S. Subotić, "Odnosi s javnošću u post-industrijskom društvu,' Srpska politička misao, 2009, br. 4, str. 373-392,

[8] S. Fajgelj, "Metode istraživanja ponašanja", Centar za primenjenu psihologiju, Beograd 2007.

[9] M. Miletić, N. Miletić, "Komunikološki leksikon", Megatrend univerzitet, Beograd 2012. 


\section{INTERNET MARKETING AND MEDIA PROMOTION OF EDUCATIONAL INSTITUTIONS}

\begin{abstract}
:
In this paper we investigate and critically analyze the possibilities of educational institutions that in today's business environment to promote on the Internet. Reputation of public institutions must be maintained by using modern communications and marketing strategies, media promotion and maintenance of good relations with the public. Towards this end should go through the application of modern scientific knowledge of Communication and interdisciplinary accomplishments in the field of computer science, economics, marketing, management and psychology. The information society requires new approaches to social communication, thus improving communication practice becomes imperative. The imperative is placed in front of educational institutions that are supposed to carry out organizational alignment to the requirements of modern society and to develop and implement communications and marketing strategies in planning and organizing daily activities. Modern marketing strategies involve the application of the Internet in context and perspective. Marketing strategy helps organizations to promote and position in their environment, and thus improve their business. Educational institutions along with other organizations are included in the commercial relationship and start "competition" with other organizations. In order to survive the competition, the organizational and logistical sense, it is necessary to continuously develop economic, marketing and communication strategies at global and local levels, including the Internet as a powerful electronic media which is frequently used for media promotion.
\end{abstract}

Key words:

Internet, marketing, educational institutions, media promotion. 